\title{
SKA2 Gene
}

National Cancer Institute

\section{Source}

National Cancer Institute. SKA2 Gene. NCI Thesaurus. Code C118352.

This gene plays a role in microtubule binding and chromosome segregation. 